\title{
PELAKSANAAN PENYALURAN KREDIT PADA PT. BANK RAKYAT INDONESIA (PERSERO) TBK UNIT PANTI
}

\author{
Lestrinelhuda, Ratna Widayati \\ Akademi Keuangan dan Perbankan Padang \\ ratnawidayati@akbpstie.ac.id
}

\begin{abstract}
ABSTRAK
Tujuan penelitian ini adalah untuk mengetahui prosedur yang harus dipenuhi oleh calon debitur untuk memperoleh kredit dari bank, serta mengetahui proses penyelesaian kredit yang bermasalah. Jenis penelitian ini adalah bersifat deskriptif dengan menggunakan metode analisa data kualitatif, yaitu menganalisa pelaksanaan penyaluran kredit pada PT. Bank Rakyat Indonesia (Persero) Tbk Unit Panti. Kesimpulan 1) PT. Bank Rakyat Indonesia (Persero) Tbk Unit Panti telah menyalurkan kredit sesuai dengan ketentuan dan prosedur yang telah ditetapkan yaitu mulai dari pengenalan atau pendekatan kepada calon debitur, tahap permohonan kredit, analisa kredit, tahap persetujuan kredit, administrasi, realisasi kredit (pencairan kredit) sampai tahap pengawasan hingga kredit tersebut benar-benar dilunasi. 2) PT. Bank Rakyat Indonesia (Persero) Tbk Unit Panti melakukan tahapan dalam menyelesaikan kredit bermasalah (mecet) yaitu, pertama dengan tindakan penyelamatan kredit dan kedua penyelesaian kredit. Penyelamatan kredit yaitu berusaha agar kredit tersebut lancar kembali dengan cara Rescheduling, Reconditioning dan Restructuring. Namun jika hal tersebut tidak berhasil maka bank akan melakukan tindakan penyelesaian kredit yang diawali secara kekeluargaan melalui perundingan-perundingan sampai akhirnya penyitaan jaminan.
\end{abstract}

Kata Kunci: Penyaluran Kredit

\section{PENDAHULUAN}

Bank adalah badan usaha yang menghimpun dana dari masyarakat dalam bentuk simpanan dan menyalurkannya kepada masyarakat dalam bentuk kredit dan atau bentuk-bentuk lainnya dalam rangka meningkatkan taraf hidup rakyat banyak (UU No. 10 Tentang Perbankan Tahun 1998).

Kredit adalah penyediaan uang atau tagihan yang dapat dipersamakan dengan itu, berdasarkan persetujuan atau kesepakatan pinjam-meminjam antara bank dengan pihak lain yang mewajibkan pihak peminjam untuk melunasi utangnya setelah jangka waktu tertentu dengan pemberian bunga (UU No. 10 Tentang Perbankan Tahun 1998). 
Unsur utama dalam penyaluran kredit yaitu kepercayaan (keyakinan) bahwa kredit yang diberikan akan benar-benar diterima penegembaliannya dimasa datang. Unsur ini harus disertai oleh prinsip kehati-hatian yang tinggi, karena dana kredit merupakan dana simpanan nasabah yang dititipkan pada bank.

Penyaluran kredit kepada masyarakat merupakan kegiatan utama bank yang tidak hanya memberi manfaat bagi bank, nasabah penerima kredit tetapi juga bagi pemerintah. Salah satu manfaat penting yang diperoleh bank adalah memperoleh pendapatan bunga. Bagi nasabah, kredit merupakan sumber dana yang dapat dimanfaatkan untuk mengembangkan usahanya dan bagi pemerintah, penyaluran kredit dapat mendorong pertumbuhan ekonomi secara nasional.

Bank sebagai lembaga keuangan mempunyai banyak resiko dalam mengelola dana simpanan masyarakat. Resiko yang paling sering terjadi yaitu resiko kredit. Resiko tersebut adalah terjadi kerugian yang terkait dengan kemungkinan kegagalan counterparty (debitur) dalam memenuhi kewajibannya untuk melunasi semua pinjamannya. Resiko ini sangat berbahaya bagi bank yang akhirnya menimbulkan kredit macet dan kerugian bagi bank. Jika suatu bank gagal dalam mengelola kredit yang disalurkan maka hal ini kemungkinan besar akan mempengaruhi terhadap kesehatan bank dan berkurangnya kepercayaan nasabah penyimpan untuk menyimpan dananya pada bank tersebut.

Bank harus mengelola perkreditannya dengan baik. Proses perkreditan pada dasarnya merupakan suatu proses yang terintegrasi antara sumber-sumber dana kredit, alokasi dana yang dapat dijadikan kredit dengan perencanaan (planning), pengorganisasian (organizing), penyusunan personalia (staffing), pengarahan (leading) dan pengawasan (controlling). Dari hal tersebut di atas, maka penulis tertarik untuk melakukan suatu penelitian yang berjudul "Pelaksanaan Penyaluran Kredit Pada PT. Bank Rakyat Indonesia (Persero) Tbk Unit Panti".

Berdasarkan latar belakang yang telah dikemukakan di atas, maka masalah yang dibahas yaitu:

1. Bagaimana prosedur pemberian kredit di PT. Bank Rakyat Indonesia (Persero) Tbk Unit Panti?

2. Prosedur dalam menangani nasabah yang tidak memenuhi kewajiban tepat waktu.

\section{METODE PENELITIAN}

Jenis Penelitian

Jenis penelitian ini adalah bersifat deskriptif dengan menggunakan metode analisa data kualitatif, yaitu menganalisa pelaksanaan penyaluran kredit pada PT. Bank Rakyat Indonesia (Persero) Tbk Unit Panti.

\section{Sumber Data}

Data diperoleh dengan cara melakukan penelitian langsung yaitu dengan mendatangi objek penelitian untuk mendapatkan data-data yang diperlukan untuk 
mengetahui proses penyaluran kredit yang diterapkan pada PT. Bank Rakyat Indonesia (Persero) Tbk Unit Panti.

Pelaksanaan Penyaluran Kredit Pada Pt. Bank Rakyat Indonesia (Persero) Tbk Unit Panti

Sektor Dan Lapangan Usaha Yang Dapat Diberikan Kredit

Sektor usaha yang dapat dibiayai oleh PT. Bank Rakyat Indonesia (Persero) Tbk Unit Panti pada umumnya adalah sektor usaha yang bersifat ekonomis, diantaranya adalah:

\section{Sektor Pertanian}

PT. Bank Rakyat Indonesia (Persero) Tbk Unit Panti memberikan kredit dalam usaha meningkatkan produksi pertanian dan sekaligus meningkatkan taraf hidup masyarakat petani. Kredit yang diberikan adalah dalam bentuk Kredit Usaha Tani (KUT).

Kredit Usaha Tani (KUT) ini yaitu kredit modal kerja yang diberikan kepada kelompok-kelompok tani untuk keperluan membiayai pertanian dan membantu meningkatkan hasil tani yang maksimal, karena masyarakat petani tidak lagi kekurangan dana dalam mengelola lahan pertaniannya. Kredit ini akan diberikan jika kelompok tani telah memenuhi persyaratan yang ditetapkan dan telah memiliki struktur organisasi yang resmi.

\section{Sektor Perdagangan}

Kredit yang diberikan kepada nasabah yang memiliki usaha dalam bidang perdagangan seperti pedagang kecil, grosir dan pedagang keliling dan lain-lain

\section{Sektor Perikanan dan Peternakan}

Kredit yang disalurkan digunakan untuk usaha pembibitan ikan, tambak (keramba), peternakan ayam, itik dan ternak sapi dan lain-lain

\section{Sektor Industri}

PT. Bank Rakyat Indonesia (Persero) Tbk Unit Panti membantu debitur yang memiliki usaha industri (produksi) baik rumah tangga maupun industri besar dalam meningkatkan hasil industrinya dan membantu dalam mengembangkan usahanya.

Perkembangan Kredit Pada PT. Bank Rakyat Indonesia (Persero) Tbk Unit Panti

Tabel 1

Jumlah kredit yang disalurkan

Pada PT. Bank Rakyat Indonesia (Persero) Tbk Unit Panti

\begin{tabular}{|c|c|c|c|c|c|c|c|}
\hline \multirow[t]{3}{*}{ Tahun } & \multicolumn{6}{|c|}{ Jenis-jenis kredit } & \multirow{3}{*}{$\begin{array}{l}\text { Total kredit } \\
\text { Dlm Rp / Th }\end{array}$} \\
\hline & \multicolumn{2}{|r|}{ KUR } & \multicolumn{2}{|c|}{ KUPEDES } & \multicolumn{2}{|r|}{ GBT } & \\
\hline & $\%$ & jumlah & $\%$ & jumlah & $\%$ & jumlah & \\
\hline 2007 & 30 & 306.000 .000 & 55 & 561.000 .000 & 15 & 153.000 .000 & 1.020 .000 .000 \\
\hline 2008 & 50 & 892.500 .000 & 40 & 714.000 .000 & 10 & 178.500 .000 & 1.785 .000 .000 \\
\hline
\end{tabular}

Sumber: PT. Bank Rakyat Indonesia (Persero) Tbk Unit Panti 
Tahun 2007 kredit yang disalurkan yaitu sebesar Rp 1.020.000.000,- yaitu KUR $30 \%$ dengan jumlah Rp 306.000.000,-, KUPEDES 50\% jumlah Rp 561.000.000,- dan GBT 15\% jumlah Rp 153.000.000,-. Sedangkan tahun 2008 terjadi peningkatan total kredit yang disalurkan sebesar $75 \%$ yaitu menjadi Rp 1.785.000.000,-. KUR meningkat menjadi 50\% dari total kredit yang disalurkan pada tahun tersebut dengan nominal Rp 892.500.000,-, KUPEDES mengalami penurunan pada persentase menjadi $40 \%$ yaitu Rp 714.000.000,- dan GBT juga mengalami penurunan pada persentase menjadi 10\% jumlah Rp 178.500.000,-

\section{Pelaksanaan Penyaluran Kredit}

Prosedur penyaluran kredit yang sehat ialah bahwa setiap calon debitur harus memberikan keyakinan dari berbagai aspek bahwa dirinya dapat mengembalikan kredit (pokok dan bunga) tepat pada waktunya. Apabila karena sesuatu hal kemudian ternyata debitur tidak dapat memenuhi kewajibannya, maka bank akan menyita jaminan dalam nilai yang cukup untuk membayar hutang pokok dan bunganya.

Melalui pernyataan tersebut di atas dapat diambil kesimpulan bahwa bank harus teliti dalam menyalurkan kredit. Salah satu caranya yaitu dengan menerapkan prosedur yang baik dan teratur yang sesuai dengan peraturan yang telah ditetapkan. Adapun prosedur pelaksanaan penyaluran kredit pada PT. Bank Rakyat Indonesia (Persero) Tbk Unit Panti adalah sebagai berikut:

\section{Tahap Pengenalan Atau Pendekatan}

Yaitu tahap dimana pemohon meminta penjelasan mengenai ketentuanketentuan atau syarat-syarat permohonan kredit. Pada tahap ini deskman akan menjelaskan semua keterangan mengenai jenis kredit, sistem bunga dan akan menjawab semua pertanyaan yang diajukan sehingga tidak adanya keraguan dalam diri pemohon kredit.

\section{Tahap Permohonan Kredit}

Pemohon kredit akan mengajukan permohonan dengan membawa semua syarat yang telah dijelaskan deskman.

Berkas-berkas yang dibawa pemohon kredit yaitu :

1) Surat permohonan kredit

2) KTP (Suami dan Istri)

3) Surat Keterangan Usaha

4) Surat Kelakuan baik dari Polisi atau Walinagari setempat

5) Kartu Keluarga

6) Laporan Keuangan Usahanya

7) Jaminan (Agunan)

Semua berkas dan persyaratan tersebut dibawa ke meja deskman untuk diperiksa kelengkapannya sebelum diserahkan kepada mantra kredit.

\section{Tahap Analisa Kredit}

Jika semua syarat lengkap maka dilakukan analisa terhadap pemohon kredit baik bersifat keuangan ataupun nonkeuangan (sesuai dengan analisa yang telah dijelaskan sebelumnya), tujuannya untuk mengetahui keadaan usaha pemohon secara langsung. Dalam hal ini mantri kredit akan terjun ke lapangan 
untuk melihat langsung usaha pemohon kredit, menilai apakah usaha tersebut layak untuk diberikan kredit atau tidak. Selain itu, mantri kredit juga melakukan wawancara terhadap pemohon maupun pihak lain yang bisa memberikan keterangan lengkap dan sesuai dengan kenyataan.

\section{Tahap Persetujuan Kredit}

Setelah mantri kredit selesai melakukan semua analisa, maka semua berkas akan diserahkan kepada deskman. Deskman akan membawa berkas dan hasil analisa kepada kepala unit. Diterima atau tidaknya permohonan kredit tergantung keputusan kepala unit dan hasil analisa dari mantri kredit.Biasanya keputusan kredit mencakup jumlah kredit yang akan diterima, jangka waktu kredit dan biaya-biaya yang harus dibayar oleh debitur.

\section{Administrasi}

Deskman akan melakukan pencatatan secara sistematis terhadap data pemohon dan dokumen-dokumen kelengkapan pengajuan permohonan kredit sebagai arsip bagi bank.

\section{Realisasi Kredit (Pencairan Kredit)}

Setelah kredit disetujui dan administrasi dilakukan, maka deskman akan menyerahkan sebuah slip untuk mencairkan kredit sesuai nominal yang diputuskan yang akan dibawa debitur kepada teller. Pencairan ini dapat dilakukan dengan menerima secara langsung ataupun ditransfer ke rekening debitur.

\section{Pengawasan Kredit}

Setelah kredit dicairkan dan diterima debitur, maka mantra kredit akan bertugas dalam mengawasi dan memantau usaha debitur. Pengawasan kredit merupakan proses internal control and continue control.

Pengawasan kredit yang dilakukan oleh PT. Bank Rakyat Indonesia (Persero) Tbk Unit Panti dua cara yaitu:

1) On Site Monitoring (Pengawasan Langsung)

Pengawasan yang dilakukan oleh mantri kredit dengan secara langsung mendatangi tempat usaha debitur secara rutin setiap 3 bulan sekali. Tujuan dari pengawasan ini yaitu:

a. Meneliti kebenaran data/keterangan yang disampaikan debitur.

b. Meneliti secara langsung usaha debitur.

c. Sacara psikologis, mengingatkan debitur bahwa pihak bank memberikan perhatian atas usaha debitur.

d. Mendidik debitur untk menyampaikan laporan sesuai dengan kenyataan yang ada.

2) On Desk monitoring (Pengawasan Tidak Langsung)

Pengawasan pasif yang dilakukan mantri kredit yaitu melalui instrumen administratif yang dapat memberikan informasi mengenai gejalagejala penyimpangan yang berdampak terhadap kolektibilitas kredit. Hal ini dapat dilihat dari laporan keuangan yang diberikan debitur, apakah laporan tersebut sesuai dengan kenyataan atau hanya rekayasa. 


\section{Pelunasan Kredit}

Debitur membayar semua kewajibannya kepada bank sesuai dengan kesepakatan. Pembayaran dilakukan secara angsurang yang dibayar per bulan dan terdiri dari angsuran pokok ditambah angsuran bunga.

\section{Kolektibilitas Kredit}

Dalam penyaluran kredit, bank akan menghadapi berbagai macam situasi yang salah satunya jika debitur tidak membayar kewajibannya tepat pada waktunya, debitur menghilang dan sebagainya. Kredit yang disalurkan memiliki tingkatan kolektibilitas yang mempunyai akhir pada tahap kemacetan.

PT. Bank Rakyat Indonesia (Persero) Tbk Unit Panti menetapkan kolektibilitas kreditnya sebagai berikut:

1. Kredit Lancar

Belum dikategorikan ke dalam kredit bermasalah karena nasabah masih membayar semua kewajibannya tepat waktu dan sesuai dengan kesepakatan kredit yang telah disepakati di awal.

2. Kredit Kurang Lancar

Telah terlihat gejala-gejala yang dapat digolongkan ke dalam kredit bermasalah karena nasabah mulai melakukan kelalaian dengan menunggak angsuran kreditnya dalam satu atau dua bulan namun belum ada tanda-tanda bahwa debitur menyimpang dari perjanjian kredit. Jangka waktu dari tahap ini yaitu selama 90 hari kerja. Jika dalam waktu tersebut debitur belum juga membayar kewajibannya, maka kreditnya akan memasuki tahap berikutnya.

3. Dalam Perhatian Khusus (DPK)

Debitur tidak mampu membayar kewajiban dalam tenggang waktu yang diberikan. Dalam tahapan ini bank akan memberikan suatu perhatian kepada debitur dan akan memeberikan suatu penjelasan secara kekeluargaan tentang sumua kewajiban debitur. Tenggang waktu pada tahap ini yaitu 90 hari kerja.

4. Diragukan

Pada tahap ini debitur sudah mulai melanggar dan sudah secara sengaja tidak membayar kewajibannya, perhatian dan penyuluhan yang diberikanpun siasia. Jika pada tahap ini debitur belum juga memenuhi semua kewajibannya maka kredit dalam keadaan siaga I bagi bank. Tenggang waktu pada tahap ini yaitu 30 hari kerja.

5. Kredit Macet

Tahap ini sudah sangat merugikan bank karena nasabah sudah benar-benar tidak memenuhi kewajibannya lagi dan mungkin bisa saja debitur tersebut sudah menghilang (kabur). Jika hal ini benar terjadi maka kredit jelas tidak akan diterima lagi pengembaliannya dan bank mengalami kerugian. Kredit macet tidak akan dicoret begitu saja oleh bank, namun akan dimasukkan ke kategori cadangan piutang tak tertagih.Tahap ini diberikan tenggang waktu selama 60 hari. Jika pada tenggang waktu yang ditentukan debgitur belum juga menunjukkan itikad baik untuk membayar semua kewajibannya, maka bank akan menarik (menyita) jaminan. 


\section{Penyelesaian Kredit Bermasalah (Macet) oleh PT. bank Rakyat Indonesia (Persero) Tbk Unit Panti}

Dalam menyelesaikan kredit bermasalah (macet), pihak Bank Rakyat Indonesia melakukan dua cara yang didahului dengan tindakan penyelematan pada kredit dengan kemungkinan bahwa kredit tersebut kembali lancar. Namun jika hal tersebut tidak berhasil dilakukan maka Bank Rakyat Indonesia akan melakukan penyelesaian sesuai aturan sehingga tidak menimbulkan kerugian yang besar bagi bank.

\section{Penyelamatan Kredit}

Sekalipun bank dalam memberikan kredit tidak pernah menginginkan bahwa kredit yang diberikan akan menjadi kredit bermasalah dan untuk keperluan itu pihak bank akan melakukan berbagai upaya preventif yang mungkin dilakukan untuk mencegah agar kredit tidak bermasalah. Namun idak mustahil pada akhirnya kredit tetap saja bermasalah bahkan keadaan kredit itu bukan saja tidak lancar atau diragukan melainkan akhirnya macet.

Untuk memperbaiki atau memperlancar kredit yang semula tergolong diragukan atau macet, bank melakukan tindakan penyelamatan kredit agar menjadi kredit lancar lagi.

Tindakan penyelamatan kredit yang dilakukan oleh PT. Bank Rakyat Indonesia (Persero) Tbk. Unit Panti adalah:

1) Rescheduling (Penjadwalan Kembali)

Perubahan syarat kredit yang hanya menyangkut jadwal pembayaran dan atau jangka waktu

2) Reconditioning (Persyaratan Kembali)

Perubahan sebagian atau seluruh syarat kredit yang tidak terbatas pada perubahan jadwal pembayaran, jangka waktu, dan atau persyaratan lainnya sepanjang tidak menyangkut perubahan maksimum saldo kredit.

3) Restructuring (Penataan Kembali)

Perubahan syarat-syarat kredit yang menyangkut:

a. Penambahan Dana oleh Bank

b. Konversi seluruh atau sebagian tunggakan bunga menjadi pokok kredit baru

c. Konversi seluruh atau sebagian dari kredit menjadi penyertaan dalam perusahaan yang dapat disertai dengan penjadwalan kembali dan atau persyaratan kembali.

\section{Penyelesaian Kredit}

Apabila menurut pertimbangan bank, kredit yang bermasalah tidak mungkin terselamatkan dan menjadi lancar kembali melalui upaya-upaya penyelamatan sehingga akhirnya kredit tersebut menjadi macet, maka bank akan melakukan tindakan-tindakan penyelesaian atu penagihan kredit macet tersebut. Penyelesaian tersebut merupakan upaya bank untuk memperoleh kembali pembayaran baik dari nasabah debitur dan atau penjamin atas kredit bank. 
Walaupun bank tidak mengharapkan terjadinya kredit macet, seluruh pejabat bank terutama berkaitan dengan perkreditan harus memiliki pandangan dan persepsi yang sama dalam menangani kredit macet tersebut. Kerena itu untuk menyelesaikan kredit macet tersebut perlu menggunakan pendekatan sebagai berikut:

1) Bank tidak membiarkan atau menutupi adanya kredit bermasalah (macet).

2) Bank harus mendeteksi secara dini adanya kredit bermasalah atau diduga akan menjadi kredit bermasalah.

3) Penanganan kredit bermasalah atau diduga bermasalah harus dilakukan secara dini dan sesegera mungkin.

4) Bank tidak melakukan penyelesaian kredit bermasalah dengan cara menambah plafont kredit atau tunggakan-tunggakan bunga dan mengkapitalisasi tunggakan bunga tersebut atau yang lazim dikenal dengan praktek plafondering kredit.

5) Bank tidak boleh melakukan pengecualian dalam penyelesaian kredit bermasalah, khususnya untuk kredit bermasalah kepada pihak-pihak yang terkait dengan bank dan debitur-debitur tertentu.

Dalam menyelesaikan kredit bermasalah PT. Bank Rakyat Indonesia (Persero)

Tbk Unit Panti melakukan:

1. Perundingan dengan debitur yang bersifat kekeluargaan

Yaitu bank berbicara secara kekeluargaan dengan debitur dan mengimbau pada debitur agar melunasi kewajibannya atau mencari jalan keluar yang baik bagi kedua belah pihak dan tidak merugikan salah satu pihak.

2. Penyerahan Pada Badan Pengurusan Kredit Macet yaitu PUPN

Jika cara kekeluargaan tidak berhasil maka PT. Bank Rakyat Indonesia (Persero) Tbk Unit Panti akan menyerahkan kredit macet kepada PUPN (Panitia Urusan Piutang Negara) adalah lembaga pemerintahan yang bertugas mengurus piutang Negara.

3. Proses Gugatan Perdata

Bank akan melakukan gugatan secara perdata ke pengadilan jika debitur melanggar perjanjian kredit. Setelah ditetapkan keputusan pengadilan yang telah mempunyai kekuatan pasti, maka PT. Bank Rakyat Indonesia (Persero) Tbk Unit Panti akan dapat menagih secara paksa kreditnya dengan membawa surat penagihan resmi dari pengadilan

4. Penagihan Oleh Penagih Utang (Debt Collector) Swasta

Jika semua tahap telah ditempuh dan belum menunjukkan itikad baik dari debitur, maka benk akan melakukan penagihan yang memaksa melalui debt collector. PT. Bank Rakyat Indonesia (Persero) Tbk Unit panti biasanya membawa polisi untuk menagih piutangnya, bukanlah premanpreman. 
5. Pelelangan Jaminan (Agunan)

Langkah terakhir yang dilakukan bank dalam menyelesaikan $\mathrm{kr}$ bermasalah dan menghindari kerugian yang lebih besar, biasanya $r \mathbf{r}$. Bank Rakyat Indonesia (Persero) Tbk Unit Panti akan melakukan penarikan dan pelelangan barang atau benda yang dijadikan jaminan atau agunan oleh debitur pada saat mengajukan permohonan kredit.

\section{KESIMPULAN}

Berdasarkan uraian pada bab-bab sebelumnya dapat diambil kesimpulan sebagai berikut:

1. PT. Bank Rakyat Indonesia (Persero) Tbk Unit Panti telah menyalurkan kredit sesuai dengan ketentuan dan prosedur yang telah ditetapkan yaitu mulai dari pengenalan atau pendekatan kepada calon debitur, tahap permohonan kredit, analisa kredit, tahap persetujuan kredit, administrasi, realisasi kredit (pencairan kredit) sampai tahap pengawasan hingga kredit tersebut benar-benar dilunasi.

2. PT. Bank Rakyat Indonesia (Persero) Tbk Unit Panti melakukan tahapan dalam menyelesaikan kredit bermasalah (mecet) yaitu, pertama dengan tindakan penyelamatan kredit dan kedua penyelesaian kredit. Penyelamatan kredit yaitu berusaha agar kredit tersebut lancar kembali dengan cara Rescheduling, Reconditioning dan Restructuring. Namun jika hal tersebut tidak berhasil maka bank akan melakukan tindakan penyelesaian kredit yang diawali secara kekeluargaan melalui perundingan-perundingan sampai akhirnya penyitaan jaminan.

\section{DAFTAR PUSTAKA}

Alanshari, F., \& Marlius, D. (2018). Prosedur Pemberian Kredit KPR Pada PT. Bank Tabungan Negara (Persero) TBK Cabang Pembantu Bukittinggi. https://doi.org/10.31227/osf.io/rsfhc

Amelia, L., \& Marlius, D. (2018). Pengendalian Kredit Dalam Upaya Menciptakan Bank Yang Sehat Pada PT. Bank Pembangunan Daerah Sumatera Barat Cabang Utama Padang. https://doi.org/10.31227/osf.io/kpc64

Andriani, B., \& Susanto, R. (2019). Pengawasan Kredit PT. Bank Perkreditan Rakyat (BPR) Ophir Pasaman Barat. https://doi.org/10.31219/osf.io/aunvc

Auzar Luky, 1999. Manajemen Perbankan. Padang: Fakultas Ilmu-Ilmu Sosial UNP.

Dahlan Siamat, 2004. Manajemen Lembaga Keuangan Edisi Keempat. Jakarta: Fakultas Ekonomi UI. 
Febriansyah, I., \& Afriyeni, A. (2019). Penyelesaian Kredit Bermasalah PT. Bank Pembangunan Daerah (BPD) Sumbar Cabang Alahan Panjang Kabupaten Solok. https://doi.org/10.31219/osf.io/vutmj

Fuady Munir, 1996.Hukum Perkreditan Kontemporer. Bandung: PT. Citra Aditiya Bakti.

Hani Handoko, 1984. Manajemen Edisi 2. Yogyakarta: BPFB.

Ikbal, M., \& Marlius, D. (2017). Pengaruh Jumlah Taksiran Dan Uang Pinjaman Terhadap Laba Bersih Pada PT. Pegadaian (UPC) Gurun Laweh. https://doi.org/10.31227/osf.io/uch4a

Kasmir, 2002. Dasar-dasar Perbankan. Jakarta: Raja Grafindo Persada.

Lampiran Undang-Undang RI No. 10 Tahun 1998 Tentang Perubahan Atas UndangUndang No. 7 Tahun 1992 Tentang Perbankan.

Pratama, D., \& Fernos, J. (2019). Prosedur Pelaksanaan Kredit Usaha Rakyat (KUR) Pada PT. Bank Nagari Cabang Padang. https://doi.org/10.31227/osf.io/ag68j

Supramono Gatot,1995. Perbankan Dan Masalah Kredit: Suatu Tinjauan Yuridis. Jakarta: Djambatan

Thomas Suyatno. DKK, 1995. Dasar-dasar Perkreditan. Jakarta: PT. Gramedia Pustaka Utama.

Widayati, R. (2019). Aktivitas Pemberian Kredit Usaha Pada PT. Bank Perkreditan Rakyat Batang Kapas. https://doi.org/10.17605/OSF.IO/EDPN4

Yasman, R., \& Afriyeni, A. (2019). Prosedur Pemberian Kredit Pada PT. Bank Pekreditan Rakyat (BPR) Jorong Kampung Tangah (JKT) Pariaman Cabang Padang. https://doi.org/10.31219/osf.io/c5ufr 